\title{
Produção de biossólido agrícola por meio da compostagem e vermicompostagem de lodo de esgoto
}

\author{
Rodrigo S. Corrêa ${ }^{1}$, Yone M. F. Fonseca ${ }^{2}$ \& Anelisa S. Corrêa ${ }^{3}$
}

\begin{abstract}
RESUMO
Normas recentes não permitem que biossólidos com significativas concentrações de patógenos humanos sejam usados na agricultura. Dessa forma, o trabalho visa avaliar a exeqüibilidade de se produzir biossólido isento de patógenos por meio da compostagem e vermicompostagem do lodo de esgoto de Brasília. Serragem e poda de árvores e de grama foram misturadas com lodo de esgoto, como fontes de carbono e material estruturante, em pilhas de compostagem. O composto maduro foi então inoculado com minhocas, para ser vermicompostado. As minhocas se desenvolveram bem e melhoraram as características físicas e sanitárias do biossólido compostado. O lodo de esgoto apresentava, originalmente, 4,7 ovos viáveis de helmintos por grama de matéria seca e o processo de compostagem reduziu essa concentração para valores entre não-detectáveis a 0,34 ovos viáveis de helmintos por grama de material seco, que representa uma eficiência de desinfestação entre 93 e 100\%. Não foram detectados ovos viáveis de helmintos após a vermicompostagem e, portanto, o processo se mostrou capaz de produzir biossólidos livres de helmintos, que são permitidos para o uso agrícola no Brasil.
\end{abstract}

Palavras-chave: helmintos, patógenos, estabilização, higienização

\section{Production of agricultural biosolid by composting and vermicomposting sewage sludge}

\begin{abstract}
ABSTRAC
Recent Brazilian regulations do not allow biosolids rich in human pathogens to be used in agriculture. Thus, this work aimed to evaluate the feasibility of producing pathogen-free biosolids by composting and vermicomposting sewage sludge from city of Brasilia. Sawdust and woodchips or yard trimmings were mixed with tertiary sewage sludge as carbon source and bulk agent to build piles bigger than $5 \mathrm{~m}^{3}$. Mature compost was then inoculated with worms to be vermicomposted. Worms developed well and improved the physical and sanitary characteristics of the composted sludge. The sewage sludge originally presented 4.7 viable eggs $\mathrm{g}^{-1}$ of dry solids and the composting process could reduce it to values from non-detectable to 0.34 viable eggs $\mathrm{g}^{-1}$ of dry solids. Such figures represent sanitation efficiencies from 93 to $100 \%$. Nonviable eggs were detected after vermicomposting. Therefore, such a process showed itself capable of producing helminthefree biosolids, which are allowed for agricultural use in Brazil.
\end{abstract}

Key words: helminthes, pathogens, stabilization, hygienization

1 EFL/UnB. Campus Universitário Darcy Ribeiro - CP 04401, CEP 70.910-900, Brasília, DF. Fone: (61) 92115452. E-mail: rodmanga@yahoo.com.br

2 Semarh/DF. SBS Q. 02 Lote 06, CEP: 70.070-120, Brasília, DF. Fone: (61) 33072700. E-mail: yonefonseca@yahoo.com.br

${ }^{3}$ Centro de Estudos Sociais e Ambientais. CP 10.814, CEP 70.324-980, Brasília, DF. Fone: (61) 92317768. E-mail: zizas@zipmail.com.br 


\section{INTRODUÇÃO}

O esgoto doméstico bruto constitui-se de 99,9\% de água e $0,1 \%$ de matéria sólida (Metcalf \& Eddy, 1991). Os processos de tratamento de esgoto visam separar a parte sólida da líquida para que o efluente tratado possa ser liberado em corpos receptores sem causar danos ao meio ambiente. Nesse processo, poluentes, nutrientes e contaminantes são concentrados em uma massa denominada lodo de esgoto, que é subproduto do tratamento. Quanto mais avançado e eficiente for o processo de tratamento de esgoto, maior será a quantidade de lodo produzido, que deve ser gerenciado e disposto adequadamente no meio ambiente. Cidades que aumentaram a coleta e o nível de tratamento de esgotos têm-se defrontado com dificuldades em gerenciar e dispor adequadamente o lodo gerado (Epstein, 2003).

Para incentivar o uso de lodo de esgoto e seus derivados, sobretudo na agricultura, o termo biossólido foi criado e divulgado em todo o mundo. Biossólidos são definidos, pela USEPA (1995), como qualquer produto orgânico resultante do tratamento de esgotos, que pode ser beneficamente utilizado ou reciclado. Beneficamente implica ausência de danos ambientais e de prejuízos para a saúde de animais e humanos (USEPA, 1995). Todavia, há toda sorte de organismos em lodos de esgotos, tais como vírus, bactérias, protozoários e helmintos. Como resultado, questões relacionadas à saúde pública invariavelmente confrontam o aproveitamento desses resíduos.

O estabelecimento de concentrações máximas de ovos viáveis de helmintos em lodos de esgoto tem sido critério mundialmente utilizado para se permitir o uso agrícola desse material (Capizzi-Banas \& Schwartzbrod, 2001). Estudos epidemiológicos têm mostrado que a alta freqüência de helmintos na população brasileira, o longo tempo de sobrevivência dos ovos desses organismos no ambiente e a baixa dose infectante são riscos inerentes à utilização agrícola de lodos de esgotos no País (Soccol et al., 1997). Em escala mundial, são 3,5 bilhões de pessoas infectadas por helmintos ou enteroprotozoários, a maioria crianças, resultando em aproximadamente 60 mil óbitos causados por Ascaris lumbricoides e 70 mil por Entamoeba histolytica a cada ano (WHO, 2000 apud Castiñeiras \& Martins, 2003). Por esses motivos e em nome da segurança sanitária, o Decreto Federal $n^{\circ} 4.954 / 2004$ restringiu, no Brasil, o uso agrícola de insumos e resíduos que contenham significativas concentrações de metais e patógenos (MAPA, 2004).

A agência Norte-Americana de Proteção Ambiental (USEPA) disciplinou, por meio da norma "Title 40 of the Code of Federal Regulations (CFR), Part 503”, o uso de biossólidos em solos, relacionando-os ao risco potencial que representam para a saúde humana e para o meio ambiente. Essa norma enumera os possíveis usos de biossólidos após serem tratados por meio de Processos para Significantemente Reduzir Patógenos - PSRP (compostagem, secagem a calor, caleação, radiação solar e outros) com base na concentração de organismos patogênicos remanescentes após o tratamento. Os PSRP em lodos de esgoto, descritos na norma "U.S. EPA CFR Part 503” (USEPA, 1995), e respectivas concentrações tole- ráveis de patógenos e metais, têm servido de referência para diversos países, inclusive para o Brasil.

O Estado de São Paulo, baseado na “CFR 40 Part 503” (USEPA, 1995), regulamentou a utilização agrícola de biossólidos por meio da Norma Técnica N/CETESB/P4.230 (CETESB, 1999). O IAP (s.d.) elaborou norma mais adaptada às condições regionais e estabeleceu a concentração máxima de 0,25 ovos viáveis de helmintos por grama de matéria seca para biossólidos que podem ser empregados na agricultura daquele Estado (IAP, sem data). Esse valor também é adotado nos Estados Unidos para biossólidos de uso irrestrito na agricultura e na jardinagem (USEPA, 1995). O Conselho de Meio Ambiente do Distrito Federal (CONAM/ DF, 2006) e o Conselho Nacional do Meio Ambiente elaboraram a Resolução CONAM/DF n ${ }^{\circ}$ 03/2006 e a Resolução CONAMA no $375 / 2006$, respectivamente, que recepcionam os limites paranaenses para concentração de ovos viáveis de helmintos em biossólidos Classe A, que serão os únicos permitidos na agricultura brasileira a partir de 2011 (CONAMA, 2006); assim, o limite de 0,25 ovos viáveis de helmintos por grama de matéria seca será padrão brasileiro para biossólidos de uso agrícola.

A coleta e o tratamento de esgotos no Distrito Federal DF, superam $90 \%$ da quantidade produzida por uma população de aproximadamente 2,2 milhões de habitantes, resultando na produção de $270 \mathrm{Mg}$ por dia de lodo, que atingirá cerca de $400 \mathrm{Mg}$ por dia nos próximos dois anos. Os lodos de esgoto produzidos no DF possuem potencial para uso agrícola, pois apresentam concentrações de metais aquém dos valores máximos estabelecidos pelo CONAM/DF (2006) e CONAMA (2006) (Tabela 1); entretanto, excesso de umidade (86 a 88\%), rápida putrefação e a presença de significativas concentrações de helmintos e suas formas de resistência (4 a 13 ovos viáveis por grama de matéria seca) representam, atualmente, obstáculos para o aproveitamento agrícola de lodos de esgotos no Distrito Federal.

Dos inóculos patogênicos presentes nos lodos de esgoto produzidos no DF, os ovos de helmintos se situam entre os mais resistentes aos processos de higienização (PSRP). Sendo assim, importância epidemiológica, baixa dose de infecção e alta resistência habilitam ovos de helmintos como indicadores de eficiência dos PSRP e de contaminação remanescente em biossólidos (Capizzi-Banas \& Schwartzbrod, 2001).

A compostagem e a aplicação de cal a lodos de esgoto são os dois PSRP mais utilizados em todo o mundo. A compostagem é um processo barato, resulta em um produto estável e com teores mais elevados de matéria orgânica e de nutrientes que o lodo tratado com cal (Corrêa, 2001). A vermicompostagem, que é resultado da ação detritívora das minhocas e da microflora que vive em seu trato digestivo, é outro processo utilizado para a higienização e estabilização de lodos de esgoto. A vermicompostagem representa um passo adicional no controle de patógenos e na humidificação da matéria orgânica presente em biossólidos compostados. A depender da eficiência do processo, a compostagem pode esterilizar lodos de esgotos (Epstein, 1997). Caso o produto auferido não alcance a desinfestação desejada, o biossólido 
compostado servirá de matéria-prima para a vermicompostagem (Eastman, 1999).

Visando atender às normas brasileiras que regulamentam o uso agrícola de biossólidos no País (MAPA, 2004; CONAM/DF, 2006 e CONAMA, 2006), objetivou-se, com este trabalho, verificar a viabilidade de se compostar e vermicompostar o lodo de esgoto produzido no Distrito Federal e avaliar a eficiência desses processos na higienização desse material.

\section{MATERIAL E MÉTODOS}

Este trabalho foi desenvolvido no pátio de estocagem de lodo da Estação de Tratamento de Esgoto Brasília Norte (ETE Brasília Norte), operada pela Companhia de Saneamento Ambiental do Distrito Federal - CAESB. A Estação produz $60 \mathrm{Mg}$ por dia de lodo de esgoto, que é originado de tratamentos primário, secundário (lodo biologicamente ativado) e terciário (polido com sulfato de alumínio). Após deságüe em prensa mecânica, o lodo é liberado para o pátio de estocagem, contendo entre 86 e $88 \%$ de umidade (Tabela 1).

Tabela 1. Principais características do lodo de esgoto e das fontes de carbono utilizados nas pilhas de compostagem

\begin{tabular}{lccc}
\hline Parâmetro & Lodo de esgoto & Serragem & Podas \\
Umidade $(\%)$ & $86-88$ & $9-10$ & $17-22$ \\
Densidade $\left(\mathrm{Mg} \mathrm{m}^{-3}\right)$ & $1,1-1,2$ & $0,5-0,6$ & $0,4-0,5$ \\
Carbono total $\left(\mathrm{g} \mathrm{kg}^{-1}\right)$ & $310-330$ & $320-360$ & $580-598$ \\
Nitrogênio total $\left(\mathrm{g} \mathrm{kg}^{-1}\right)$ & $51-59$ & $0,7-0,9$ & $2,1-2,9$ \\
Relação $\mathrm{C} / \mathrm{N}$ & $5,8: 1$ & $425: 1$ & $206: 1$ \\
Alumínio $\left(\mathrm{g} \mathrm{kg}^{-1}\right)$ & $2,3-3,7$ & $\mathrm{ND}$ & $\mathrm{ND}$ \\
Fósforo total $\left(\mathrm{g} \mathrm{kg}^{-1}\right)$ & 31 a 60 & $<0,4$ & $5-21$ \\
Potássio $\left(\mathrm{g} \mathrm{kg}^{-1}\right)$ & $2 \mathrm{a} 6$ & $<0,02$ & $2-7$ \\
Arsênio $\left(\mathrm{mg} \mathrm{kg}^{-1}\right)$ & $<0,6$ & $\mathrm{ND}^{*}$ & $\mathrm{ND}$ \\
Cádmio $\left(\mathrm{mg} \mathrm{kg}^{-1}\right)$ & $4-6$ & $\mathrm{ND}^{*}$ & $\mathrm{ND}^{*}$ \\
Chumbo $\left(\mathrm{mg} \mathrm{kg}^{-1}\right)$ & $10-11$ & $\mathrm{ND}^{*}$ & $\mathrm{ND}$ \\
Cobre $\left(\mathrm{mg} \mathrm{kg}^{-1}\right)$ & $87 \mathrm{a} 104$ & $\mathrm{ND}^{*}$ & $\mathrm{ND}^{*}$ \\
Cromo $\left(\mathrm{mg} \mathrm{kg}^{-1}\right)$ & $18-21$ & $\mathrm{ND}^{*}$ & $\mathrm{ND}^{*}$ \\
Mercúrio $\left(\mathrm{mg} \mathrm{kg}^{-1}\right)$ & $<4$ & $\mathrm{ND}^{*}$ & $\mathrm{ND}^{*}$ \\
Molibdênio $\left(\mathrm{mg} \mathrm{kg}^{-1}\right)$ & $<7$ & $\mathrm{ND}^{*}$ & $\mathrm{ND}^{*}$ \\
Níquel $\left(\mathrm{mg} \mathrm{kg}^{-1}\right)$ & $5-6$ & $\mathrm{ND}^{*}$ & $\mathrm{ND}^{*}$ \\
Selênio $\left(\mathrm{mg} \mathrm{kg}^{-1}\right)$ & $<1,3$ & $\mathrm{ND}^{*}$ & $\mathrm{ND}^{*}$ \\
Zinco $(\mathrm{mg} \mathrm{kg}$ & $159-169$ & $\mathrm{ND}^{*}$ & $\mathrm{ND}^{*}$ \\
\hline
\end{tabular}

Fontes: Companhia de Saneamento Ambiental do Distrito Federal - CAESB, Handreck (1998), Jenkins (1994)

${ }^{*} \mathrm{ND}$ - não determinado

O sistema de compostagem escolhido foi o de pilhas de aeração passiva de dimensão $\geq 5 \mathrm{~m}^{3}$. Nesse sistema, o revolvimento periódico das pilhas garante o ambiente aeróbico necessário à atividade dos microrganismos e uma homogeneização melhor da mistura em processo de compostagem (Handreck, 1998). A evolução em escala desse sistema resulta no processo denominado leira de aeração passiva (Figura 1), cujo princípio operacional é semelhante ao das pilhas. Material carbonáceo (serragem, podas) adicionado nas proporções certas ao lodo de esgoto e entre três e cinco revolvimentos de cada leira são suficientes para garantir a efi- ciência do processo de compostagem (Corrêa, 2001). Devido ao baixo custo e à facilidade operacional, a compostagem em leiras é o sistema mais utilizado em todo o mundo, sendo particularmente apropriado para países de clima tropical (Epstein, 1997).

Amostras de duas fontes de carbono (serragem e poda de árvores e grama) e de lodo de esgoto foram coletadas e as concentrações de carbono e nitrogênio totais foram analisadas por meio da combustão seca, conforme descrito em Corrêa et al. (2005). A disponibilidade de grande quantidade de serragem e de podas no Distrito Federal e a obtenção gratuita delas foram premissas de seleção desses materiais. Há grande quantidade de palha de arroz no DF, que é muita apropriada para a compostagem. Porém, seu valor comercial a descarta como alternativa economicamente viável em sistemas comerciais de compostagem de lodos de esgoto.

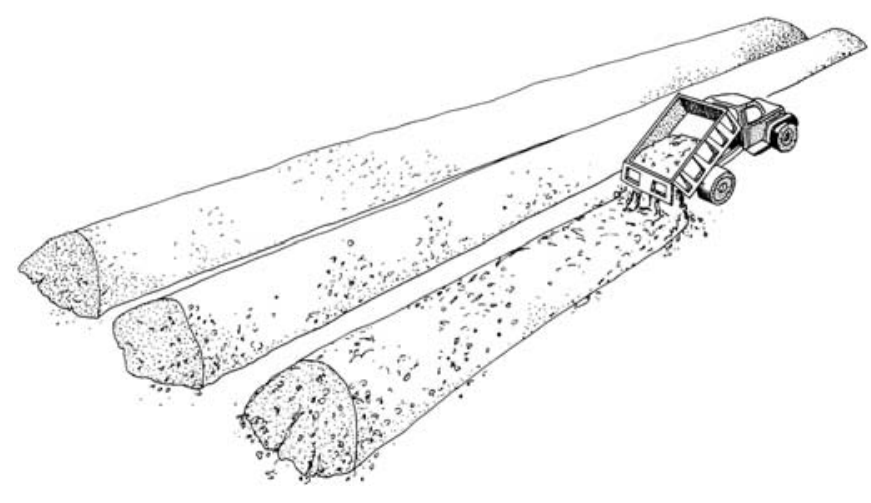

Figura 1. Sistema de compostagem em leiras de aeração passiva

Dois processos de mistura (na caçamba do caminhão e no pátio) foram aqui testados. A mistura de serragem diretamente na caçamba visou estimar a viabilidade de instalação de um silo de serragem e podas acima do local de carregamento do lodo, próximo à saída da prensa, que facilitaria o sistema de compostagem em leiras de aeração passiva (Figura 1). Apesar do maior investimento inicial, haveria substancial otimização do espaço no pátio de compostagem e economia de hora-máquina (pá-carregadeira), que é empregada para misturar e revolver as leiras.

A quantidade dos ingredientes utilizados nas pilhas de compostagem ( $\mathrm{kg}$ de matéria seca $\rightarrow \mathrm{m}^{3}$ ) foi calculada visando-se obter relações carbono/nitrogênio entre 20 a 35:1 (Tabelas 1 e 2), de acordo com a fórmula abaixo:

Relação $\frac{\mathrm{C}}{\mathrm{N}}=\frac{(360 \mathrm{~kg} \times 32 \% \mathrm{C} \text { no lodo }+900 \mathrm{~kg} \times 34 \% \mathrm{C} \text { na serragem })}{(360 \mathrm{~kg} \times 5,5 \% \mathrm{~N} \text { no lodo }+900 \mathrm{~kg} \mathrm{x} 0,08 \% \mathrm{~N} \text { na serragem })}$

$\rightarrow$ Relação $\frac{\mathrm{C}}{\mathrm{N}}=23: 1$

Determinou-se a viabilidade de compostagem dos materiais selecionados por meio de seis pilhas, cada uma de aproximadamente $6,5 \mathrm{~m}^{3}$. As pilhas 1,2 e 3 foram misturadas na caçamba e utilizaram serragem, como fonte de carbono, e cavaco de madeira produzido pelo Departamento de Parques e Jardins da NOVACAP, como material 
Tabela 2. Volumes de ingredientes utilizados na montagem das pilhas de compostagem e relação $\mathrm{C} / \mathrm{N}$ inicial de cada pilha

\begin{tabular}{lcccccc}
\hline & \multicolumn{5}{c}{ Ingrediente } \\
\cline { 2 - 5 } Pilha & $\begin{array}{c}\text { Lodo de } \\
\text { esgoto }\end{array}$ & Serragem & $\begin{array}{c}\text { Cavaco de } \\
\text { madeira }\end{array}$ & $\begin{array}{c}\text { Podas de } \\
\text { grama e } \\
\text { árvores }\end{array}$ & $\begin{array}{c}\text { Volume } \\
\text { final da } \\
\text { mistura }\end{array}$ & $\begin{array}{c}\text { Relação } \\
\text { C/N da } \\
\text { mistura }\end{array}$ \\
\cline { 2 - 6 } Pilha 1 & 3,0 & 1,5 & 3,0 & - & 6,5 & $21,3: 1$ \\
Pilha 2 & 3,0 & 1,5 & 3,0 & - & 6,5 & $21,3: 1$ \\
Pilha 3 & 3,0 & 1,5 & 3,0 & - & 6,5 & $21,3: 1$ \\
Pilha 4 & 3,0 & 2,0 & 3,0 & - & 6,8 & $26,3: 1$ \\
Pilha 5 & 3,0 & - & - & 5 & 7,0 & $25,4: 1$ \\
\hline Pilha 6 & 3,0 & 3,0 & 3,0 & - & 7,5 & $36,4: 1$ \\
\hline
\end{tabular}

estruturante para uma aeração melhor. Uma amostra composta de dez sub-amostras do lodo de esgoto utilizado nas pilhas foi coletada e enviada ao laboratório para análise de ovos viáveis de helmintos, conforme método descrito em Yanko (1987). A mistura de ingredientes das pilhas 4, 5 e 6 ocorreu no pátio com a utilização de uma pá-carregadeira. Nas três últimas pilhas se utilizaram diferentes proporções e/ou fontes de carbono (Tabela 2). As diferentes proporções de ingredientes visaram à avaliação de diferentes misturas de compostagem. Não se umedeceram as misturas durante o processo de compostagem e a única fonte de água das pilhas foi a existente no lodo de esgoto (88\% de umidade). Cada pilha foi mecanicamente revirada três vezes durante o processo, para se obter melhor aeração e homogeneização da mistura e, também, para se cumprir os critérios estabelecidos pela USEPA (1995).

A temperatura das pilhas, tomada a cada dois dias com um termômetro digital $\left(100^{\circ} \mathrm{C} \pm 0,1^{\circ} \mathrm{C}\right)$, foi o parâmetro utilizado para monitorar a compostagem, pois o calor liberado durante o processo é indicador da eficiência de estabilização e higienização do material orgânico da pilha (Epstein, 1997; Geisler, 2000; Jenkins, 1994). A haste de metal do termômetro foi inserida até a profundidade de um metro, em cinco pontos de cada pilha, e médias foram calculadas considerando-se as cinco leituras. Quando umidade, ar e nutrientes estão em proporções satisfatórias, o metabolismo dos organismos termofílicos da compostagem eleva a temperatura até valores próximos a $80^{\circ} \mathrm{C}$ (Epstein, 1997). Temperaturas acima de $55^{\circ} \mathrm{C}$, por no mínimo cinco dias, são consideradas essenciais para higienização de pilhas que contêm lodo de esgoto (USEPA, 1995). Nesse nível de atividade retratado pelo calor, há significativa eliminação de organismos patogênicos (Epstein, 1997).

Ao final do processo de compostagem das pilhas 1, 2 e 3, uma amostra composta de cada pilha foi coletada e enviada ao laboratório para o exame em duplicata de ovos viáveis de helmintos, seguindo-se o método descrito por Yanko (1987). Após retornarem à temperatura ambiente (cerca de 60 dias), as pilhas 1,2 e 3 foram transferidas individualmente para minhocários de $1,5 \mathrm{~m}^{3}$ cada uma, construídos de alvenaria e com teto de plástico. Cada pilha foi inoculada com aproximadamente $300 \mathrm{~g}$ de uma mistura constituída de minhocas vermelhas da Califórnia (Eisenia foetida) e minhocas africanas (Eudrilus eugeniae). O material em processo de ver- micompostagem foi umedecido semanalmente com água potável. Ao final da vermicompostagem, amostras compostas dos vermicompostos 1 , 2 e 3 foram coletadas e enviadas para análise de ovos viáveis de helmintos, conforme método descrito em Yanko (1987).

As pilhas 4, 5 e 6 foram invadidas por minhocas ainda no pátio, ao final do processo de compostagem, antes que pudessem ser transferidas para os minhocários; assim, os resultados das análises parasitológicas delas foram descartados, uma vez que não foi possível separar a ação de higienização da compostagem da proporcionada pela vermicompostagem.

\section{RESULTADOS E DISCUSSÃO}

\section{Desempenho do processo de compostagem do lodo de esgoto}

Os organismos da compostagem exigem que resíduos contenham cerca de $60 \%$ de umidade (massa/massa), $20-40 \%$ de porosidade, $\mathrm{pH}$ entre 5 e 8 , nutrientes e uma relação carbono/nitrogênio (C/N) em torno de 25:1 (Geisler, 2000). A adição de $1-2 \mathrm{~kg}$ de serragem e cavaco de madeira ou $3 \mathrm{~kg}$ de poda (Tabela 2) para cada quilo de matéria seca contida no lodo de esgoto (fonte de umidade, nitrogênio e outros nutrientes) foi suficiente para que os critérios da compostagem fossem atendidos. Dessa forma, todas as misturas testadas neste trabalho (Tabela 2) mostraram-se compostáveis (Figura 2) e atingiram a temperatura mínima de $55^{\circ} \mathrm{C}$ necessária para a higienização de pilhas que contêm material de origem fecal (USEPA, 1995).

Há três fases de temperatura em pilhas de compostagem, que indicam uma sucessão de microrganismos saprofíticos: organismos mesofílicos, presentes no início do processo, elevam a temperatura para cerca de $45^{\circ} \mathrm{C}$ (primeira fase mesofílica). Nesse estágio ocorre o desenvolvimento de organismos termofílicos, que aumentam a taxa de decomposição da matéria orgânica e, como conseqüência, a temperatura atinge valores entre $55-80^{\circ} \mathrm{C}$ (fase termofílica). Com a exaustão da matéria orgânica, há um decréscimo na população de organismos termofílicos, enquanto organismos mesofílicos responsáveis pela síntese de matéria húmica e fúlvica passam a dominar a pilha, durante a segunda fase mesofílica (temperaturas entre $45^{\circ} \mathrm{C}$ e ambiente) (Epstein, 1997). A passagem por essas três fases é fundamental para a decomposição e transformação do material orgânico original. Além disso, a sucessão de microrganismos saprofíticos auxilia a eliminação de patógenos humanos, por meio da competição, predatismo e parasitismo. Golueke (1975) mostrou que patógenos humanos sobrevivem mais tempo quando expostos somente a temperaturas entre $55-80{ }^{\circ} \mathrm{C}$ do que quando colocados em contato com microrganismos da compostagem; portanto, o estabelecimento de uma comunidade saprofítica em pilhas de compostagem é essencial para se garantir a higienização de lodos de esgoto.

As pilhas 1 a 5 completaram as três fases da compostagem em aproximadamente dois meses e as pilhas 1,2 e 3 atingiram temperaturas máximas acima de $60{ }^{\circ} \mathrm{C}$. A adição de $25 \%$ a mais de serragem à mistura da pilha 4 reduziu 
sensivelmente o tempo de compostagem (Figura 2). O aumento da serragem em 50\%, em relação à quantidade empregada na pilha 4 , foi capaz de reduzir ainda mais o tempo de compostagem da pilha 6 , que se limitou a um mês (Figura 2). Porém, a adição de maiores quantidades de serragem à mistura acarreta maior custo de transporte de serragem e/ou poda e a relação econômica entre custo e benefício quanto à mistura ideal deve ser cuidadosamente avaliada em sistemas de compostagem (Geisler, 2000). Thomas (1990) ressalta que a maioria dos objetivos da compostagem pode ser alcançada entre duas e quatro semanas, mas um composto maduro e estável requer entre oito e doze semanas de processamento.

O volume final da mistura de lodo de esgoto com material carbonáceo foi cerca de $25 \%$ inferior à soma do volume dos dois ingredientes separadamente (Tabela 2). A adição de $2 \mathrm{~m}^{3}$ de serragem a $3 \mathrm{~m}^{3}$ de lodo de esgoto, por exemplo, rendeu uma pilha de aproximadamente $4 \mathrm{~m}^{3}$. A alta porosidade das fontes de carbono e a absorção de água do lodo pela serragem e pelas podas foram responsáveis pela redução volumétrica da mistura.

\section{Viabilidade da compostagem do lodo de esgoto da ETE} Brasília Norte

A compostagem é um processo de estabilização, higienização e desidratação de lodos de esgoto (Epstein, 1997). A degradação da matéria orgânica e a perda de água durante a compostagem resultaram em um volume final de composto inferior a 50\% daquele que iniciou o processo, representando uma perda de água de cerca de 30\% em relação à mistura inicial e uma conseqüente concentração de sólidos de $60 \%$. A mistura do lodo com as fontes de carbono mostrou-se úmida, pegajosa e com forte odor. A perda d’água e a estabilização da matéria orgânica putrescível do lodo resultaram em um produto leve, solto e com odor característico das substâncias húmicas.

O biossólido compostado deve ser peneirado para que haja reaproveitamento do cavaco de madeira, reduzindo ainda mais o volume final a ser transportado. A ETE Brasília Norte produz $60 \mathrm{Mg}$ por dia de lodo de esgoto, que contém entre 86 e $88 \%$ de umidade. São 52 toneladas de água e oito toneladas de matéria seca contidas no lodo, que são diariamente transportadas para fora da estação. A compostagem diária das $60 \mathrm{Mg}$ de lodo de esgoto, utilizando a mistura da pilha 4 (Tabela 1), necessitaria de vinte pilhas diárias de $7 \mathrm{~m}^{3}$ cada uma, que acarretariam na produção diária de $40 \mathrm{Mg}$ de composto com cerca de $50 \%$ de umidade.

Em um sistema de compostagem em leiras de aeração passiva (Figura 1), cada pilha adicionada à leira ocuparia $16 \mathrm{~m}^{2}$, ou $320 \mathrm{~m}^{2}$ por dia. Para um ciclo de 60 dias, um pátio de 2,5 ha pode alojar 1.200 pilhas e prover área suficiente para a manobra de veículos; outra opção para se reduzir a área necessária de pátio seria fornecer, aos interessados, o biossólido após a fase termofílica, cerca de um mês após o início do processo (Figura 2). A segunda fase mesofílica, entre o $30^{\circ}$ e o $60^{\circ}$ dias, poderia ficar a cargo adquirente do composto, que seria devidamente instruído sobre os procedimentos a serem adotados.

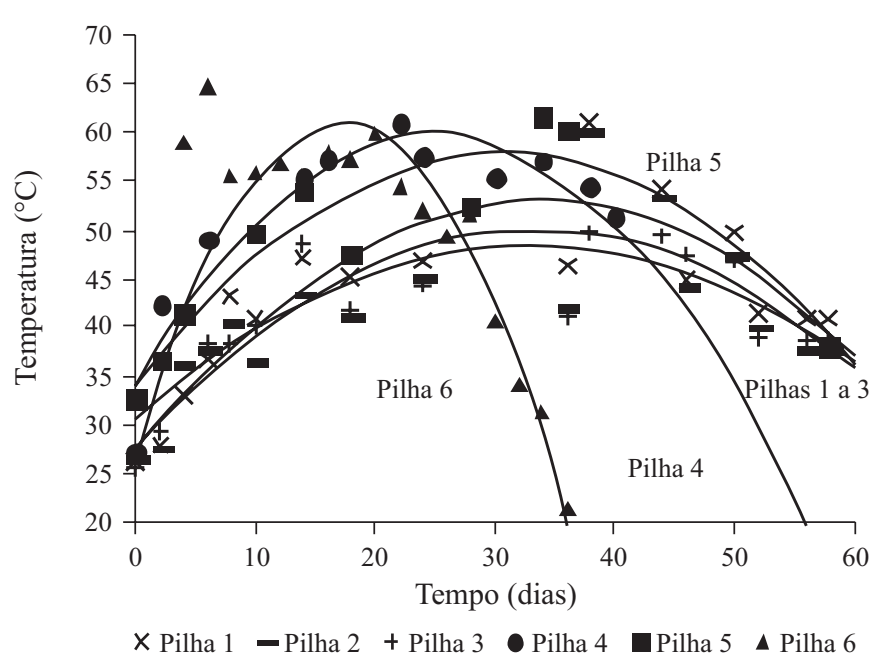

Figura 2. Temperatura das pilhas 1 a 6 durante o processo de compostagem

\section{Desempenho do processo de vermicompostagem}

A vermicompostagem do material compostado ocorreu em um período superior a trinta dias, com grande desenvolvimento das minhocas, sobretudo da espécie africana, e notório aumento do número de indivíduos. A fragmentação do composto pelas minhocas reduziu o seu volume em cerca de 25\%, fato freqüentemente citado na literatura (Eastman, 1999). A ação detritívora das minhocas e da microflora que vive no seu trato digestivo fragmenta e digere material orgânico, reduzindo o seu volume. O biossólido compostado, estável, friável e com boa aeração, mostrou-se adequado como matéria-prima para a vermicompostagem.

\section{Controle de ovos de helmintos}

A questão sanitária é o principal motivo para que resíduos originados de esgotos sejam tratados por meio da compostagem e vermicompostagem (Eastman, 1999; Masciandaro et al., 2000). O lodo utilizado como matéria-prima no processo de compostagem apresentava 4,7 ovos viáveis de helmintos por grama de matéria seca (Tabela 3). O processo de compostagem mostrou eficiência de eliminação de ovos viáveis de helmintos entre 93 a 100\%. Fernandes et al. (1996) compostaram lodo de esgoto e conseguiram reduzir em até 86\% o número de ovos viáveis de helmintos originalmente presentes na mistura a ser compostada. Soccol et al. (1997) compostaram lodo de esgoto com serragem e alcançaram entre 93 e 100\% de redução do número de ovos viáveis de helmintos. Explicam os autores que a maior parte da higienização do lodo ocorreu após a fase termofílica da compostagem, o que corrobora os estudos que indicam que a eliminação dos patógenos ocorre por meio da combinação de temperaturas elevadas e relações desarmônicas entre patógenos humanos e organismos saprofíticos (Golueke, 1975).

A compostagem do lodo de esgoto da ETE Brasília Norte mostrou-se capaz de produzir material isento de ovos viáveis de helmintos e material com concentração $\leq 0,25$ ovos viáveis por grama de matéria seca, limite estabelecido para lodo de esgoto e biossólidos Classe A (CONAMA, 2006); porém a pilha 3 permaneceu com 0,34 ovos viáveis por grama de matéria seca após a segunda fase mesofílica (Tabela 3). A 
Tabela 3. Concentração de ovos viáveis de helmintos recuperados no lodo de esgoto, no biossólido compostado e no vermicompostado (nº de ovos viáveis por grama de matéria seca)

\begin{tabular}{|c|c|c|c|c|c|c|c|}
\hline Organismo & Lodo de esgoto & Pilha compostada 1 & Pilha compostada 2 & Pilha compostada 3 & Vermicomposto 1 & Vermicomposto 2 & Vermicomposto 3 \\
\hline Trichuris sp. & $1,4 \pm 0,1$ & $N D^{\star *}$ & $N D^{\star *}$ & $0,16 \pm 0,1$ & $N D^{* *}$ & $N D^{\star \star}$ & $N D^{\star \star}$ \\
\hline Ascaris sp. & $3,3 \pm 0,1$ & $0,12 \pm 0,1$ & $N D^{\star *}$ & $0,18 \pm 0,1$ & $N D^{\star *}$ & $N D^{\star *}$ & $N D^{* *}$ \\
\hline Total & $4,7 \pm 0,3$ & $0,12 \pm 0,1$ & $N D^{\star *}$ & $0,34 \pm 0,3$ & $N D^{* *}$ & $N D^{\star *}$ & $N D^{* *}$ \\
\hline
\end{tabular}

** ND - não detectado

vermicompostagem, entretanto, foi capaz de eliminar os ovos viáveis de helmintos remanescentes nas pilhas de biossólido compostado e se mostrou capaz de produzir material que atende a legislação brasileira (MAPA, 2004; CONAMA, 2006).

A vermicompostagem é considerada mais eficiente na higienização de lodos de esgoto que a compostagem. Dionísio \& Ressetti (1997) eliminaram 100\% dos ovos e larvas viáveis de Ascaris lumbricoides, Enterobius vermicularis e ancilostomídeos ao inocularem minhocas da espécie Eisenia fetida em biossólido compostado. Segundo os autores, minhocas possuem melhor desenvolvimento quando criadas em materiais contaminados por patógenos humanos, tais como coliformes fecais, protozoários e outros, pois esses patógenos lhes servem de alimento.

Resseti et al. (1999) inocularam minhocas da espécie Eudrilus eugeniae em pilhas de biossólido compostado e também eliminaram 100\% dos ovos viáveis de Acaris sp., Trichuris sp., Hymenolepis nana, $H$. diminuta e Toxocara sp. remanescentes nesse material. Projetos em escala piloto e real têm demonstrado a viabilidade de se utilizar a vermicompostagem para eliminar ovos de helmintos e outros parasitas de lodos de esgoto (Eastman, 1999). Apesar disso, Resseti et al. (1999) alertam que as larvas dos helmintos eclodem e permanecem vivas nos tecidos, no celoma e na hemocele das minhocas, que podem servir de veículo de infecção ao homem e outros animais. Portanto, apesar de serem eficientes na eliminação de helmintos, minhocas utilizadas como agentes de higienização devem ficar confinadas ao local de processamento dos resíduos e serem utilizadas exclusivamente para esse propósito. Evita-se, assim, que minhocas hospedeiras de patógenos humanos contaminem outras áreas.

\section{CONCLUSÕES}

1. O lodo de esgoto produzido na ETE Brasília Norte mostrou-se compostável por meio de pilhas de aeração passiva.

2. As misturas que compostaram com maior eficiência foram as usadas nas pilhas 4 e 6 . O lodo pode ser também satisfatoriamente compostado quando misturado a poda de árvores e grama (pilha 5).

3. A mistura dos ingredientes diretamente na caçamba foi menos laboriosa que aquela feita no pátio, com pá-carregadeira.

4. A eficiência de eliminação de ovos viáveis de helmintos por meio da compostagem variou entre 93 e 100\%, atingido, na maioria dos casos, concentrações que atendem à legislação brasileira para biossólidos Classe A.

5. O biossólido compostado serviu adequadamente de matéria-prima para a vermicompostagem.
6. Após a vermicompostagem não se detectaram ovos viáveis de helmintos no biossólido compostado.

\section{LITERATURA CITADA}

Capizzi-Banas, S.; Schwartzbrod, J. Irradiation of Ascaris ova in sludge using an electron beam accelerator. Water Research, Amsterdam, v.35, n.9, p.2256-2260, 2001.

Castiñeiras, T. M. P. P.; Martins, F. S. V. Infecções por helmintos e enteroprotozoários. Centro de Informação em Saúde para Viajantes - CIVES. http://www.cives.ufrj.br/informes/ helmintos/. 26 Dez. 2005.

CONAM/DF - Conselho de Meio Ambiente do Distrito Federal. Resolução nº 03/2006, de 18/7/2006. Diário Oficial do Distrito Federal no 138 , de 20/7/2006, p.10.

CONAMA - Conselho Nacional do Meio Ambiente. Resolução $n^{0}$ 375/2006, de 29/8/2006. http://www.mma.gov.br/port/conama/ legiano/. 29 Set. 2006.

CETESB - Companhia de Tecnologia de Saneamento Ambiental. Aplicação de lodos de sistemas de tratamento biológico em áreas agrícolas - critérios para projeto e operação - Manual Técnico, P-4.230, 1999. 32p. Mimeo.

Corrêa, R. S. Beneficial use of biosolids based on their N and P fertilising value. Melbourne: The University of Melbourne, 2001. 305p. Tese Doutorado

Corrêa, R. S.; White, R. E.; Weatherley, A. J. Biosolids effectiveness to yield ryegrass based on their nitrogen content. Scientia Agricola, Piracicaba, v.62, n.3, p.274-280, 2005.

Dionísio, J. A.; Resseti, R. R. Avaliação da capacidade da minhoca Eisenia fetida (Savigny, 1826) de desinfecção e desinfestação do lodo de esgoto. Sanare, Revista Técnica da Sanepar, Curitiba, v.8, n.8, p.50-55, 1997.

Eastman, B. R. Achieving pathogen stabilization using vermicomposting: Spiking the biosolids. BioCycle, v.40, n.11, p.62-64, 1999.

Epstein, E. The science of composting. $1^{\text {st }}$ ed. Lancaster: Technomic Publishing Company Inc. 1997. 225p.

Epstein, E. Land application of sewage sludge and biosolids. 1.ed. London, New York, Washington: Lewis Publishers. 2003. 220p.

Fernandes, F.; Andraus, S.; Andreoli, C. V.; Bonnet, B. J. C. Canto, L. A.; Medeiros, M. L. B. Eficiência dos processos de desinfecção do lodo da ETE-Belém com vista a seu uso agrícola. Sanare, Revista Técnica da Sanepar, Curitiba, v.5, n.5, p.46-58, 1996.

Geisler, M. Composting biosolids and food wastes. In: Compost 2000 Downunder Conference, 2000, Melbourne. Proceedings... Melbourne: DMP Conference Organisers, 2000. 9p.

Golueke, C. G. Composting - a study of the processes and its principles. Emmaus: Rodale Press Inc Book Division. 1975. 235p. 
Handreck, K. A. Composting - making soil improver from rubbish. 8.ed. Australia: CSIRO, Division of Soils. Soils Series, 1998. 19p. IAP - Instituto Ambiental do Paraná. Instrução normativa para a reciclagem agrícola de lodo de esgoto, sem data. 25p. Mimeo s/d

Jenkins J. C. The humanure handbook: A guide to composting human manure. 1.ed. Grove: Jenkins Publishing, 1994. 198p.

Masciandaro G.; Ceccanti B.; Garcia, C. "In situ” vermicomposting of biological sludges and impacts on soil quality. Soil Biology \& Biochemistry, Amsterdam, v.32, n.7, p.1015-1024, 2000.

Metcalf Eddy. Wastewater engineering. Treatment, disposal, and reuse. 3.ed. Singapore: McGraw-Hill, Inc. International Edition, Civil Engineering Series, 1991. 1334p.

MAPA - Ministério da Agricultura, Pecuária e Abastecimento. Decreto no 4.954, de 14/1/2004. http://www.planalto.gov.br. 10 Dez. 2004.

Ressetti, R. R.; Soccol, V. T.; Kaskantzis Neto, G. Aplicação da vermicompostagem no controle patogênico do composto de lodo de esgoto. Sanare, Revista Técnica da SANEPAR, Curitiba, v.12, n.12, p.61-70, 1999.
Soccol, V. T.; Paulino, R. C.; Castro, E. A.; Tracz, J. Eficácia dos diferentes processos de tratamento do lodo na redução da viabilidade de ovos de helmintos. Sanare, Revista Técnica da SANEPAR, Curitiba, v.8, n.8, p.24-32, 1997.

Thomas, I. Production and marketing of sewage products for ornamental horticulture. In: The Agricultural and Horticultural Use of Sewage Products, 1990, New South Wales. Proceedings... New South Wales: University of Western Australia - Hawkesbury Campus and The Australian Institute of Agricultural Science New South Wales Branch, 1990. Paper Nr. 2.

USEPA - United States Environmental Protection Agency. A guide to the biosolids risk assessments for the EPA Part 503 rule, 1995. Washington: Office of Wastewater Management, EPA/ 832-B-93-005, 1995. 195p. Mimeografado.

Yanko, T. Método analítico para ovos de helmintos viáveis. Brasília: Versão expandida por Yanko. Companhia de Saneamento do Distrito Federal, 1987. 3p. 